\title{
Osteopetrorickets - A Paradoxical Association between Osteopetrosis and Rickets - A Rare Case Report
}

\author{
Ramesh R, Madhan Jeyaraman*, Kartavya Chaudhari and Shivaraj B \\ Department of Orthopaedics, JJM Medical College, India
}

Submission: January 21, 2019; Published: February 12, 2019

*Corresponding author: Madhan Jeyaraman, Junior Resident, Department of Orthopedics, JJM Medical College, Davangere, Karnataka, India

Abstract

Background: Osteopetrosis is a rare autosomal recessive disorder, characterized by failure of osteoclasts to resorb bone leading to impairment of bone modelling and remodelling. The defect in bone turnover results in skeletal fragility despite increased bone mass. Despite high positive total body calcium balance, rickets arises when the serum calcium-phosphorus product is insufficient to mineralize newly formed Chondroid and Osteoid. When both these conditions are seen in the same patient, it is called 'Osteopetrorickets', a paradoxical association.

Case report: A 2 years 5months old female child presented with h/o inability to walk and bear weight and recurrent respiratory tract infections. The child was anaemic, with prominent ricketic features. On systemic examination, the patient had hepatosplenomegaly. Laboratory investigations showed severe anaemia, thrombocytopenia, hypocalcemia, hypophosphatemia, decreased Vit D3 and elevated serum PTH \& serum alkaline phosphatase levels. The skeletal survey revealed features of rickets, sclerosis of skull and long bones, and bone in bone appearance. Fundus examination showed B/L optic atrophy. Otological examination BERA showed B/L sensorineural hearing loss. CT scan of long bones showed diffuse cortical sclerosis of all long bones.

Discussion: Malignant infantile osteopetrorickets is a rare paradoxical association. The diagnosis of the condition is by regular biochemical and sradiological investigations. Here the patient showed improvement with supplemental calcium, calcitriol and blood transfusion. Definitive treatment is HLA identical bone marrow transplantation. Death usually occurs in early childhood due to bleeding, anaemia and infections.

Conclusion: Early diagnosis and treatment should be instituted for patients with high index of suspicion with ricketic features and prompt genetic counselling has to be done regarding the nature of inheritance pattern of diseases.

Keywords: Osteopetrorickets; Autosomal recessive; Calcitriol; Bone marrow transplantation

\section{Introduction}

Malignant infantile osteopetrosis is an autosomal recessive and a rare congenital disorder of bone resorption. The genetic defect is due to the mutations in the gene coding for an osteoclast specific vacuolar pump (TCIRG1 subunit) [1]. Despite the failure of osteoclasts to resorb immature bone, the formation of abnormal cavity in the bone ensues. Pathologically, there is a persistence of the primary spongiosa characterised by cores of calcified cartilage within bone. Abnormal remodelling of primary, woven bone results in "brittle" bone which is prone to fracture [2]. The co-existence of features of osteopetrosis and rickets in a same individual result in a paradoxical condition called Osteopetrorickets [2,3]. Here in this article, we have reported a case with classical features of osteopetrorickets and its management.

\section{Case Report}

A 2 years 5 months old female child brought by mother born to first issue of second-degree consanguineous couple delivered by birth natural presented with h/o inability to walk and bear weight and recurrent respiratory tract infections. This child was born to a consanguineously married couple. The child had global developmental delay with an IQ of 50 . The child was short, with height of $94 \mathrm{~cm}$ and weight $13 \mathrm{~kg}$, which were $<5$ centile on NCHS charts. On head to toe examination, the patient was anaemic, with prominent eyes, frontal and parietal bossing, short trunk dwarfism, craniotabes, pectus excavatum, costochondral beading, widening and broadening of wrists, bowed knees and double malleoli (as shown in figure 1-3).

Onsystemicexamination, the patienthadhepatosplenomegaly without any significant cardiac and neurological manifestations.

The patient was evaluated for further which revealed the following findings:

a) Hematological investigations showed severe anaemia ( $\mathrm{Hb}-2.9 \mathrm{~g} \%$ ) and thrombocytopenia (Platelet $0.68 \mathrm{~L} / \mathrm{cu} \mathrm{mm}$ )

b) Biochemical investigations showed hypocalcemia (7.6mg/dL), hypophosphatemia $(2.3 \mathrm{mg} / \mathrm{dL})$, Vit D3 - 4.54ng/ $\mathrm{ml}$, serum PTH $-72.5 \mathrm{pg} / \mathrm{ml}$ and serum alkaline phosphatase 759IU/L 


\section{Juniper Online Journal of Case Studies}

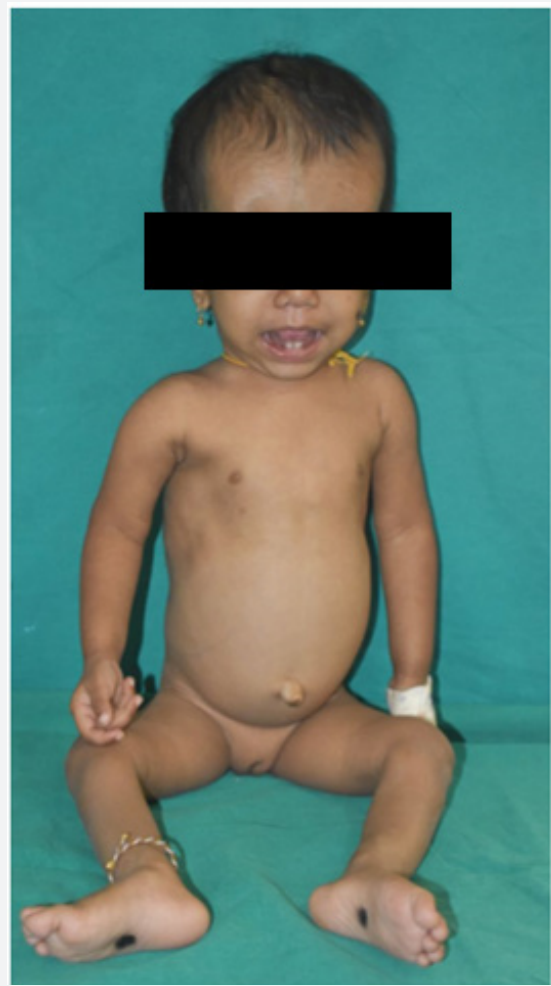

Figure 1: Features of rickets such a frontal bossing, Harrison sulcus, pectus carinatum and pot belly appearance.

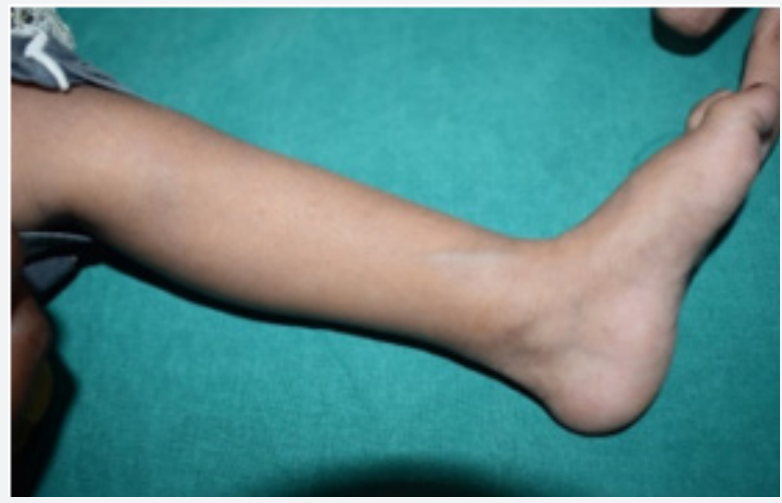

Figure 2: Double malleoli.

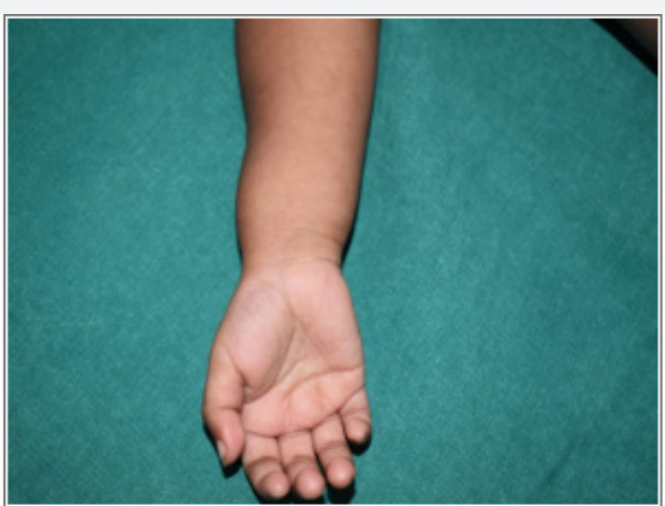

Figure 3: Widened wrist. c) Skeletal survey revealed diffuse metaphyseal widening with cupping of metaphysis, sclerosis of skull and long bones, and bone in bone appearance (Figure 4-7).

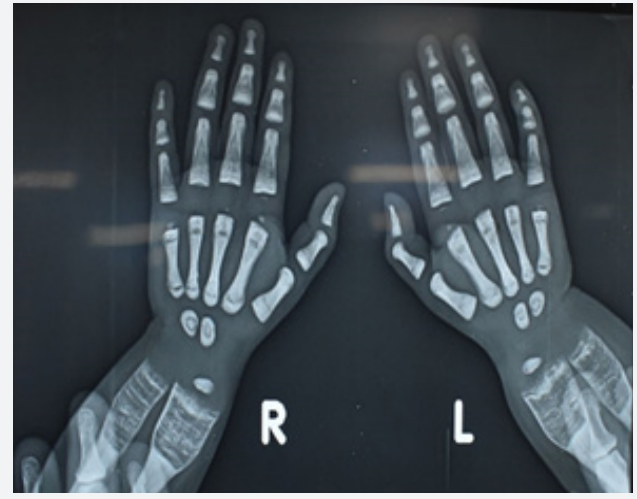

Figure 4: Radiograph of bilateral hands with wrists showing widening, cupping and splaying of metaphysis of distal radius and ulna with sclerosis of metacarpals and phalanges of bilateral hands.

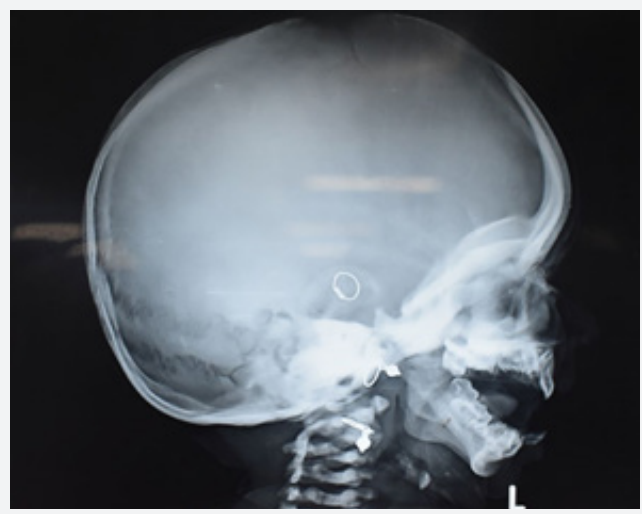

Figure 5: Radiograph of skull showing sclerosis of skull base.

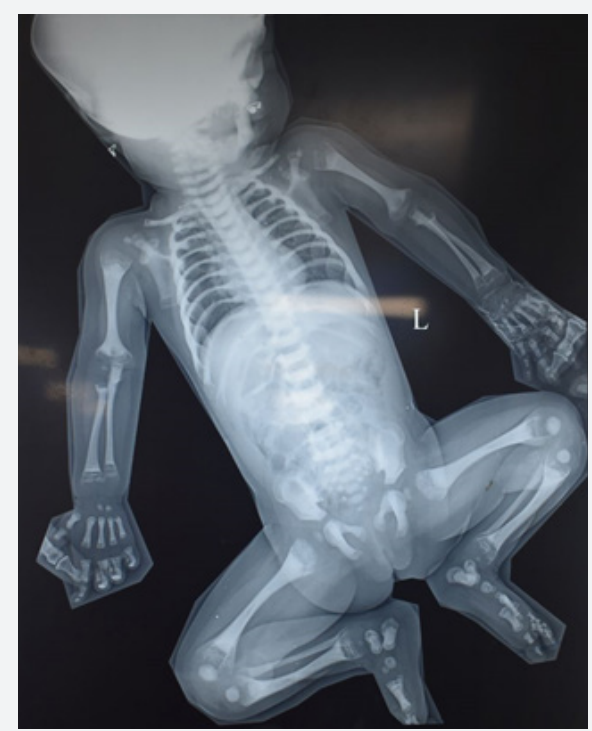

Figure 6: Babygram showing widening, cupping and splaying of metaphysis of all long bone with diffuse sclerosis of all long bones. 


\section{Juniper Online Journal of Case Studies}

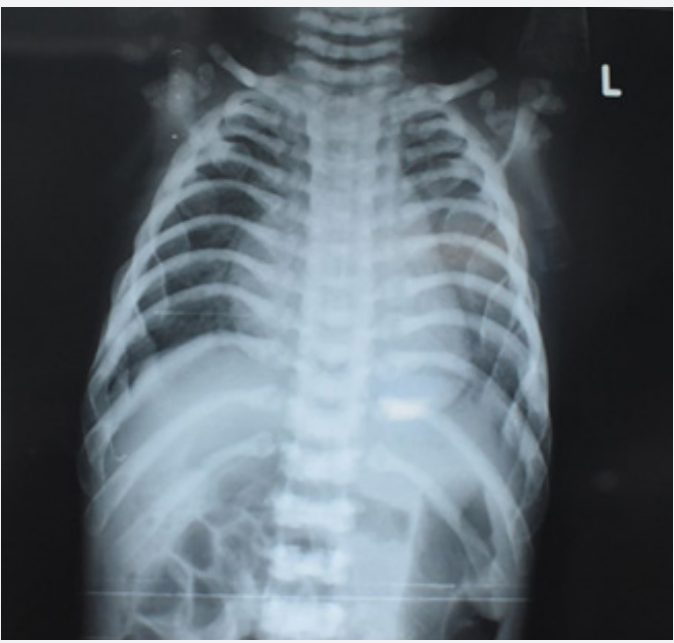

Figure 7: Radiograph of chest showing diffuse sclerosis of ribs.

d) Fundus examination showed B/L optic atrophy.

e) Otological examination BERA showed $\mathrm{B} / \mathrm{L}$ sensorineural hearing loss.

f) CT scan of long bones showed diffuse cortical sclerosis of all long bones.

The patient was treated conservatively who showed a significant improvement with supplemental syrup calcium $500 \mathrm{mg}$ twice daily for 6 months and high dose calcitriol $6,00,000 \mathrm{U}$ once intramuscular injection followed by daily 6000 units oral for 4 weeks and tapered to 400 units per day for 6 months. The patient received 6 pints of packed red blood cell transfusion. The patient was subjected for serum calcium, phosphorus, alkaline phosphatase and PTH levels every month and radiological analysis once in 2 months. The patient was followed up every month for 6 months and 6th monthly interval for 2 years which showed improvement in the general condition of the patient.

\section{Discussion}

Malignantinfantile osteopetrosis is a rare autosomal recessive disorder of osteoclast function characterized by abnormally dense bone and failure of resorption of calcified cartilage which leads to impaired bone modelling and remodelling. In this condition, despite high calcium balance, there is a failure of mineralization of chondroid and osteoid results in rickets. When both these conditions are seen in the same patient, it is called 'Osteopetrorickets', a paradoxical association [2,3].

The genetic defect is due to the mutations in the gene coding for an osteoclast specific vacuolar pump (TCIRG1 subunit) [1]. The presence of rickets worsens the symptoms of osteopetrosis. Rickets is associated with increased lethargy, irritability, poor feeding, growth retardation and pathological fractures, and hence the patient needs effective treatment. In osteopetrosis, the patients are often advised to reduce calcium intake and the osteoclasts do not respond to PTH which is responsible for maintaining calcium balance lies on the kidneys and intestine. Patients on limited calcium intake and poor intestinal absorption due to prednisolone, which is the reason for hypocalcemia and hypophosphatemia. Persistence of hypocalcemia and hypophosphatemia results in inability to mineralize the newly formed chondroid and osteoid and hence the paradoxical association of rickets and osteopetrosis results.

The criteria to diagnose Osteopetrorickets are as follows [24]

a) Recurrent infections

b) Presence of ophthalmic and ontological affection such as optic atrophy and sensorineural hearing loss

c) Clinical features of rickets: Frontal bossing, Harrison sulcus, pectus carinatum, genu varum/valgum, double malleoli

d) Biochemical investigations: Hypocalcemia and hypophosphatemia with elevated serum alkaline phosphatase and serum PTH levels.

e) Radiological features: Widening, cupping and splaying of metaphysis of long bones and diffuse sclerosis of long bones

The presence of all 5 criteria mandates to label the condition as osteopetrorickets.

The available treatment options include HLA identical bone marrow transplantation, glucocorticoid therapy, use of large doses of calcitriol and calcium [5-7]. Usually death ensues in view of anemia, bleeding and recurrent infections.

We treated our patient using high dose calcitriol and calcium along with six pints of packed red blood cell transfusions. The patient was subjected for serum calcium, phosphorus, alkaline phosphatase and PTH levels every month and radiological analysis once in 2 months. The patient has been subjected for multidisciplinary follow up for every month for 6 months and 6th monthly interval for 2 years which showed improvement in the general condition of the patient. Further follow up of the patient has to be done annually till the skeletal maturity.

\section{Conclusion}

A paradoxical condition, Osteopetrorickets, to be diagnosed early and prompt management has to be instituted to prevent further complications and death. The natural history and clinical course of the disease has been explained to the parents and genetic counselling has been given for future pregnancies. Due to lack of facilities, the genetic work up for the patient and the parents have been declined.

\section{References}

1. Elgar FJ, Worrall G, Knight JC (2002) Functional assessment of elderly clients of a rural community-based long-term care program: A 10-year cohort study. Can Jon aging-revue vandienne du vieillissement 21(3): 455-463. 
2. Brunnekref JJ, van Uden CJ, van Moorsel, Kooloos JG (2005) Reliability of videotaped observational gait analysis in patients with orthopaedic impairments. BMC-Musculoskelet Disord 6: 17-26.

3. Salch M, Murdoch G (1985) In defence of gait analysis. Observation and measurement in gait assessment. J Bone Joint Surg Br 67(2): 237-241.

4. Reid SM, Graham RB, Costigan PA (2010) Differentiation of young and older adult stair climbing gait using principal component analysis. Gait Posture 31(2): 197-203.

5. Riener R, Rabuffetti M, Frigo C (2002) Stair ascent and descent at different inclinations. Gait Posture 15(1): 32-44.

6. Senden R, Grimm B, Heyligers IC, Savelberg HHCM, Meijer K (2009) Acceleration-based gait test for healthy subjects: Reliability and reference data. Gait Posture 30(2): 192-196.

7. Maffiulett NA, Gorelick M, Kramers-de Quervain I, Bizzini M, Munzinger JP, et al. (2008) Concurrent validity and intrasession reliability of the IDEEA accelerometry system for the quantification of spatiotemporal gait parameters. Gait Posture 27(1): 160-163.

8. Mackey AH, Scott NS, Walt SE (2008) Reliability and validity of an activity monitor (IDEEA) in the determination of temporal-spatial gait parameters in individuals with cerebral palsy. Gait Posture 28(4): 634639.

9. Brandes M, Zijlstra W, Heikens S, Lummel van R, Rosenbaum D (2006) Accelerometry based assessment of gait parameters in children. Gait and Posture 24(4): 482-486.

10. MoeNilssen R, Helbostad JL (2004) Estimation of gait cycle characteristics by trunk accelerometry. J Biomech 37(1): 121-126.

11. Zijlstra W, Hof AL (2003) Assessment of spatio-temporal gait parameters from trunk accelerations during human walking. Gait Posture 18(2): 1-10.

12. Yu B, Kienbacher T, Growney ES, Johnson ME, An KN (1997) Reproducibility of the kinematics and kinetics of the lower extremity during normal stair-climbing. J Orthop Res 15(3): 348-352.
13. Moe-Nilssen R (1998) Test-retest reliability of trunk accelerometry durig standing and walking. Arch Phys Med rehabil 79(11): 13771385 .

14. Hendriksen M, Lund H, Moe Nilssen R, Bliddal H, Danneskiod-Samsoe B (2004) Test-retest reliability of trunk accelerometric gait analysis. Gait Posture 19(3): 288-297.

15. Menz HB, Lord SR, Fritzpatrick RC (2003) Acceleration patterns of the head and pelvis when walking on level and irregular surfaces. Gait Posture 18(1): 35-46.

16. Stacoff A, Diezi C, Luder G, Stussi E, Kramers-de Quervain IA (2005) Ground reaction forces on stairs : effects of stair inclination and age. Gait and Posture 21(1): 24-38.

17. Verghese J, Wang C, Xue X, Holtzer R (2008) Self-reported difficulty in climbing up or down stairs in nondisabled elderly. Arch Phys Rehabil 89(1): 100-104.

18. Liikavainio T, Isolehto J, Helminen HJ, Perttunen J, Lepola V, et al. (2007) Loading an gait symmetry during level and stair walking in asymptomatic subjects with knee osteoarthritis: importance of quadriceps femoris in reducing impact force during heel strike? The Knee 14(3): 231-238.

19. Hsu MJ, Wei SH, Yu YH, Chang YJ (2007) Leg stiffness and electromyography of knee extensors/flexors: comparison between older and younger adults during stair descent. J Rehab Res Dev 44(3): 429-436.

20. Apovian CM, Frey CM, Wood GC, Rogers JZ, Still CD, et al. (2002) Body mass index and physical function in older women. Obes Res 10(8): 740-747.

21.Vincent HK, Vincent KR, Lamb KM (2010) Obesity and mobility disability in the older adult. Obesity reviews 11(8): 568-579.

22. Bertucco M, Cesari P (2009) Dimensional analysis and ground reaction forces for stair climbing: Effects of age and task difficulty. Gait Posture 29(2): 326-331.

\begin{tabular}{|l|}
\hline \multicolumn{1}{|c|}{ Your next submission with Juniper Publishers } \\
will reach you the below assets \\
- Quality Editorial service \\
- Swift Peer Review \\
- Reprints availability \\
- E-prints Service \\
- Manuscript Podcast for convenient understanding \\
- Global attainment for your research \\
- Manuscript accessibility in different formats \\
( Pdf, E-pub, Full Text, Audio) \\
- Unceasing customer service \\
Track the below URL for one-step submission \\
https://juniperpublishers.com/online-submission.php \\
\hline
\end{tabular}

